\title{
Some Physical and Chemical Properties of Raw Flower-Honey from Erzurum Highland
}

\author{
Serap Kılıç Altun ${ }^{1}$, Mehmet Emin Aydemir ${ }^{1, *}$ \\ ${ }^{1}$ Harran University, Veterinary Faculty, Department of Food Hygiene and Technology, Şanlıurfa, Turkey
}

\section{Article History}

Received 24 December 2021

Accepted 29 December 2021

First Online 29 December 2021

\section{*Corresponding Author \\ Tel.: +905385793841 \\ E-mail: aydemiremin23@harran.edu.tr}

\begin{abstract}
In this study, the physical and chemical properties of the highland flower raw honey produced in different locations of Erzurum province were investigated. In 2019, 12 highland flower raw honeys sold during the honey harvest season were purchased from local vendors. Moisture, color, HMF, proline, acidity, $\mathrm{pH}$, conductivity, diastase number, invertase activity, C13, C13 protein-honey, C4 analysis and sugar components were analyzed in honey. It has been evaluated whether the research findings are in compliance with the Turkish Food Codex Honey Communiqué and whether they are similar to the findings of previous studies The average values of the honey samples examined in this study respectively are; moisture is $15.8 \%$, color is $41 \mathrm{~mm}$ pfund, HMF content is $4.1 \mathrm{mg} / \mathrm{kg}$, proline amount is $661.2 \mathrm{mg} / \mathrm{kg}$, acidity value is $20.4 \mathrm{meq} / \mathrm{kg}, \mathrm{pH}$ value is 3.5 , conductivity is $0.23 \mathrm{mS} / \mathrm{cm}$, diastase number was determined as $17.8 \mathrm{DN}$ and invertase activity as $189.9 \mathrm{U} / \mathrm{kg}$. The sugar ratios in honey samples were respectively average fructose $34.6 \%$, glucose $27.7 \%$, sucrose $0.5 \%$, turanose $2.6 \%$, maltose $2.8 \%$, isomaltose $2.9 \%$, erlose $0.3 \%$, fructose+glucose $62.3 \%$, fructose/glucose 1.24 , glucose/water 1.6 and trehalose, meritose, maltotriose were not detected. The difference between the protein and crude honey delta C13 values was found to be $0.29 \%$ and $\mathrm{C} 13$ value $-29 \%$ and the $\mathrm{C} 4$ sugar ratio was $1.8 \%$. As a result, it has been seen that the multifloral highland flower raw honey produced and sold in Erzurum region has high biological activity values and is in accordance with the Honey Communiqué.
\end{abstract}

\section{Introduction}

Honey is a valuable animal originated food known for its nutritional value and medicinal properties for centuries. The components in its content determine the nutritional value of honey. The composition of honey varies depending on the geographical and botanical origin, the material the bees feed on, the climatic conditions, the nectar density, the manipulations of the beekeepers, the packaging procedure, and the storage conditions (Thrasyvoulou et al., 2018). Countries determine their own regulations for the production and sale of honey in accordance with consumer health, and producers are obliged to comply with this regulation. Honey production in Turkey increased by 8.2 percent compared to the previous year in 2020 rose to 104077 tonnes (Burucu, 2021). With this amount it produces, it ranks second in honey production in the world. The aim of the Turkish Food Codex Honey Communiqué is to determine the characteristics of honey in the stages of producing, preparing, processing, storing, transporting and placing on the market hygienically and in accordance with its technique. In the codex, flower honey is defined as honey obtained from plant nectar (Turkish Food Codex, 2020). Honey must be free of all inorganic and organic additives that are not found in its natural composition. Although honey-specific regulations vary from country to country, basically the principle is that honey cannot have a unique foreign taste and odour, cannot be artificially acidified or heated 
in a way that will break down or significantly inactivate the natural enzymes it contains, and honey-specific components such as pollen cannot be removed from honey. Although the taste and aroma of honey varies depending on the source of the honey and the type of plant from which it is produced, honey should have a distinctive smell and taste. Moisture, which is a quality parameter related to the shelf life of honey, may be at different levels in honeys from different botanical origins (Machado De-Melo et al., 2018). Honey with high humidity is prone to fermentation because the osmotic pressure of the sugar is not strong enough to prevent the growth of osmophilic yeast (Bogdanov \& Martin, 2002). Hydroxymethylfurfural (HMF) is a furanic complex caused by the breakdown of sugar and is a factor of honey freshness (Gökmen, 2007). Honey is a supersaturated liquor where carbohydrates make up $95 \%$ of the dry matter, and its basic nutritional and physicochemical properties such as energy value, sweetness, granulation and viscosity depend on the compounds of these sugars (Bogdanov et al., 2008; Sabatini, 2007). Glucose and fructose are the main sugars in honey. A small quantity of other monosaccharides such as galactose have also been detected in honey varieties (Ruiz-Matute et al., 2010). The major disaccharides found in honey are $\alpha$-glucosyl derivatives of monosaccharides (Machado De-Melo et al., 2018). More than 45 disaccharides, trisaccharides, oligosaccharides and polysaccharides have been detected in trace amounts in honey (Lazaridou et al., 2004). On the other hand, sugars such as lactose, galactose, and raffinose are toxic to honeybees because they cannot digest these sugars (Herbert, 1992). Proteins such as globulins, albumins, proteases and nucleoproteins in honey originate from both bee salivary glands and plant pollen. Diastase is the most heat stable honey enzyme, so it is widely included in the honey legislation of countries as an indicator of honey bloom (Doner, 2003). The aim of this study was to investigate the physical and chemical properties of raw honey of highland flower produced in different locations of Erzurum province.

\section{Materials and Methods}

\section{Collection of honey samples}

After the honey harvest in 2019, 12 honey samples were purchased from beekeepers engaged in honey production and sales in 6 different districts of Erzurum (Oltu, Şenkaya, Olur, Uzundere, Tortum, Narman). In the analyzed samples, the statement 'raw honey from highland flowers' on the package was taken as basis. Purchased honey samples were stored in glass jars at room temperature in a darkened environment until analysis.

\section{Analyzes}

The physical and chemical properties of raw flower-honey samples were determined according to the standarts. The moisture content of honey is determined by Bogdanov et al. (2002). Sugar analysis of the honey samples was done by using HPLC - Refractive Index detector, accordance to the method proposed by Bogdanov et al. (2002). pH and acidity levels of the honey samples were identified accordance to the method proposed by Bogdanov (2009). Electrical conductivity levels were analysed by handling a conductivity meter (Meterlab-CDM230, Turkey) by the method of by Bogdanov et al. (2002). Analysis of HMF the honey samples was done by handling HPLC-UV detector (Shimadzu UV-1800, Japan) according to Turkish Standards Institute method (TSE 3036, 2002). HPLC-UV was calibrated with the solution of Hydroxymethylfurfural (HMF). Analyses were done by handling the C18-reversed-phase column below the isocratic mobile phase terms with the inclusion of $90 \%$ distilled water-10\% methanol by a flow rate of $1 \mathrm{~mL} / \mathrm{min}$ and the injection volume was $10 \mu \mathrm{L}$ (Korkmaz \& Küplülü, 2017). Diastase analyses of honey samples were identified by handling UV-Spectrophotometer (Shimadzu UV-1800, Japan), according to the method recommended by TSE method (TSE 3036, 2002). The absorbance levels of samples were measured at the 600 $\mathrm{nm}$ range of UV-Spectrophotometer for detection of the diastase activity (Bogdanov et al., 2002). The invertase activity of honey samples was determined according to German Institute for Standardization method based on the spectrophotometric measurement of p-nitrophenol (DIN 10754, 2002). Color analyzes of honey samples were made according to the method based on photometrically reading the color in terms of Pfund Scale (AOAC, 2005; Kolaylı et al., 2013). Proline contents of honey samples were analysed in accordance with the IHC method (Bogdanov, 2009). C13, C13 protein-honey, C4 analyses of honey samples were determined in accordance with the Official Methods of Analysis 998.12 (Amor, 1978). All data were analyzed statistically using SPSS 22.0 (SPSS Inc., Chicago, IL, USA) software. All results exist as the minimum, the maximum levels and mean \pm standard deviation.

\section{Results and Discussion}

The quality of honey is determined by its sensory, physical, chemical and microbiological properties. Determining the properties of honey is very important to know the quality and naturalness of honey. Some of these features are; moisture, color, acidity, $\mathrm{pH}$, conductivity, hydroxymethyl furfural content, diastase activity, reducing and non-reducing sugar content, invertase activity and proline content.

In this study, the moisture content of raw flower honey was between $15.0 \%$ and $15.9 \%$, and the average value was determined to be $15.8 \pm 0.7 \%$ (Table 1 ). Moisture content of honey may vary according to place of production, climatic conditions, degree of maturity and season (Amor, 1978). In a study conducted in 2013 
Table 1. Analysis results of honey samples

\begin{tabular}{|c|c|c|c|c|}
\hline Parameter & Unit & Minimum & Maximum & Mean \pm SD \\
\hline Moisture & $\%$ & 15.0 & 15.9 & $15.8 \pm 0.7$ \\
\hline Color & $\mathrm{mm}$ pfund & 39 & 42 & $41 \pm 0.5$ \\
\hline HMF & $\mathrm{mg} / \mathrm{kg}$ & 4.0 & 4.3 & $4.1 \pm 0.4$ \\
\hline Proline & $\mathrm{mg} / \mathrm{kg}$ & 660.2 & 662.4 & $661.2 \pm 0.6$ \\
\hline pH & - & 3.4 & 3.6 & $3.5 \pm 0.4$ \\
\hline Acidity & $\mathrm{meq} / \mathrm{kg}$ & 20.0 & 20.8 & $20.4 \pm 0.6$ \\
\hline Invertase activity & $\mathrm{U} / \mathrm{kg}$ & 187.7 & 188.9 & $189.9 \pm 0.2$ \\
\hline Diastase number & $\mathrm{DN}$ & 17.0 & 18.8 & $17.8 \pm 0.4$ \\
\hline Conductivity & $\mathrm{mS} / \mathrm{cm}$ & 0.22 & 0.24 & $0.23 \pm 0.2$ \\
\hline C13 Honey & $\%$ & -30.91 & -25.82 & $-29 \pm 0.03$ \\
\hline C13 Protein/Honey & $\%$ & -0.29 & -0.26 & $-0.29 \pm 0.7$ \\
\hline C4 & $\%$ & 1.7 & 1.9 & $1.8 \pm 0.6$ \\
\hline Fructose & $\%$ & 34.6 & 36.7 & $34.6 \pm 0.9$ \\
\hline Glucose & $\%$ & 27.7 & 29.2 & $27.7 \pm 0.6$ \\
\hline Sucrose & $\%$ & 0.5 & 0.9 & $0.5 \pm 0.4$ \\
\hline Turanose & $\%$ & 2.6 & 3.1 & $2.6 \pm 0.3$ \\
\hline Maltose & $\%$ & 2.8 & 3.7 & $2.8 \pm 0.5$ \\
\hline Isomaltose & $\%$ & 2.6 & 3.8 & $2.9 \pm 0.4$ \\
\hline Trehalose & $\%$ & ND & ND & ND \\
\hline Meritose & $\%$ & ND & ND & ND \\
\hline Maltotriose & $\%$ & ND & ND & ND \\
\hline Erlose & $\%$ & ND & 0.4 & $0.3 \pm 0.2$ \\
\hline Fructose+glucose & $\%$ & 59.4 & 64.8 & $62.3 \pm 0.8$ \\
\hline Fructose/glucose & - & 1.12 & 1.58 & $1.24 \pm 0.6$ \\
\hline Glucose/water & - & 1.2 & 1.8 & $1.6 \pm 0.2$ \\
\hline
\end{tabular}

HMF: Hydroxymethylfurfural SD: Standard deviation ND: Not detected

examining the moisture content of honey, the average moisture content of honey produced in Erzurum was reported as $15.35 \%$, and this data of the researchers is similar to the findings of our study. The moisture values measured in the honey samples in this study were below the $20 \%$ limit determined by the Turkish Food Codex Honey Communiqué and were determined to be in compliance with the standard (Turkish Food Codex, 2020).

Invertase is one of the enzymes released from the cephalic and thoracic glands of honey bees and has the highest activity in the maturation of honey (Al-Sherif et al., 2017). When the invertase values obtained within the scope of this study are compared with the ratio of IU $\geq 73.45$ (Bogdanov \& Martin, 2002) recommended by the International Honey Commission (IHC) in terms of proof and freshness of honey not being heat-treated; It was observed that all samples labeled raw honey fit very well with this measurement scale with an average of $188.5 \pm 0.2 \mathrm{U} / \mathrm{kg}$ (Table 1). In another scientific study investigating the invertase activity of six fresh raw flower honey; invertase values were found to be 178.187 U/kg on average (Şahin et al., 2020).

Diastase is an enzyme found naturally in honey and its amount varies depending on the origin of the flora, and is also an indicator of the applied heat (Çiftci, 2014; Çiftçi \& Parlat, 2018). According to the Turkish Food Codex Honey Communiqué, the number of diastases in flower honey should be 8 or more (Turkish Food Codex, 2020). In the thesis study conducted by Korkmaz and Küplülü (2017) they reported that the diastase number in five different flower honeys was between 10.8 and 14.1 on day zero. The number of diastase in honey analyzed in this study was measured between 17.0 and 18.8. When the research findings of Özgüven et al. (2020) were examined, the number of diastase in twelve honey samples varied between 9.0-25.4. The difference in the number of diastase seems to be quite variable according to the region of production, storage temperature and time.

Electrical conductivity is a parameter used to distinguish between flower and secretory honeys. It was seen that the electrical conductivity of the flower honeys examined in Özgüven et al. (2020) study varies between 0.18 and $1.05 \mathrm{mS} / \mathrm{cm}$. In the raw flower honeys examined in this study, the electrical conductivity is vaule average $0.22 \pm 0.3 \mathrm{mS} / \mathrm{cm}$, which complies with the Turkish Food Codex Honey Communiqué (Turkish Food Codex, 2020). The electrical conductivity $(0.41 \mathrm{mS} / \mathrm{cm})$ found by Albu et al. (2021) in multifloral raw honey samples in Romania is considerably higher than the findings of this study.

In this study, it was observed that the average HMF values of raw honey samples varied between approximately $4.0-4.3 \mathrm{mg} / \mathrm{kg}$, and the average was determined as $4.2 \pm 0.4 \mathrm{mg} / \mathrm{kg}$ (Table 1 ). Storing honey at an unsuitable temperature or applying heat treatment creates HMF compound depending on the bond between sugars and amino acids contained in honey (Gökmen, 2007). In the Turkish Food Codex Honey Communiqué, it is allowed to contain HMF in honey up to a maximum of $40 \mathrm{mg} / \mathrm{kg}$. The HMF values of none of 
the raw flower honeys analyzed in this study were found to be above $40 \mathrm{mg} / \mathrm{kg}$. In our study, the highest HMF value was measured as $4.3 \mathrm{mg} / \mathrm{kg}$. Batu et al. (2013) reported in their study that the HMF value of the honey sample from Rize region was $4.04 \mathrm{mg} / \mathrm{kg}$, the $\mathrm{HMF}$ value of the honey sample from Kars region was $0.15 \mathrm{mg} / \mathrm{kg}$, the HMF value of the honey sample from Malatya region was $0.96 \mathrm{mg} / \mathrm{kg}$ and the HMF value of honey sample from Erzurum region is $1.91 \mathrm{mg} / \mathrm{kg}$.

The amount of proline, one of the amino acids found in honey, should be higher than $300 \mathrm{mg} / \mathrm{kg}$ (Turkish Food Codex, 2020). It was determined that the average amount of proline in the honey samples analyzed in this study was $660.2 \pm 0.6 \mathrm{mg} / \mathrm{kg}$ and all samples were in compliance with the Turkish Food Codex Honey Communiqué. Erez et al. (2015) reported the proline amount of flower honey obtained from Pervari region as $192-234 \mathrm{mg} / \mathrm{kg}$ in 2015 . It was seen that the amount of proline in the honey analyzed by the researchers is considerably lower than the amount of proline in the honeys analyzed in this study.

The acidity of honey may vary depending on the plant source and the production region. According to the Turkish Food Codex Regulation, the total acidity of honey should not exceed $50 \mathrm{meq} / \mathrm{kg}$ (Turkish Food Codex, 2020). In our study, it was determined that the acidity average values of raw flower honeys $(20.01 \pm 0.2$ meq $/ \mathrm{kg}$ ) were in accordance with the Turkish Food Codex Honey Communique. In the study conducted by Sorkun et al. (2002) they reported the acidity of flower honey as $15 \mathrm{meq} / \mathrm{kg}$. In another study by Erdoğan et al. (2004) the acidity of honey produced in İspir district of Erzurum province was between $25.50-29.0 \mathrm{meq} / \mathrm{kg}$. The researchers' findings are consistent with the findings of this study.

The sugar ratios in honey samples were respectively average fructose $34.6 \%$, glucose $27.7 \%$, sucrose $0.5 \%$, turanose $2.6 \%$, maltose $2.8 \%$, isomaltose $2.9 \%$, erlose $0.3 \%$, fructose+glucose $62.3 \%$, fructose/glucose 1.24, glucose/water 1.6 and trehalose, meritose, maltotriose were not detected (Table 1). Average sugar rates in honey are in compliance with the Turkish Food Codex (Turkish Food Codex, 2020). The fructose/glucose ratio in honey is a parameter that shows both the crystallization tendency of honey and its origin. According to the Turkish Food Codex Honey Communiqué, the fructose/glucose ratio of raw flower honey should be between 0.9-1.4 (Turkish Food Codex, 2020). The average fructose/glucose ratio of honey samples analyzed in this study was $1.24 \pm 0.06$. Çiftçi and Parlat (2018) reported fructose/glucose ratio in flower honey as 1.05-1.19 in their research. The results of the researchers are similar to the results of this study.

The difference between the protein and crude honey delta $\mathrm{C} 13$ values was found to be $-0.29 \pm 0.03 \%$ and $\mathrm{C} 13$ value $-29 \pm 0.7 \%$ and the C4 sugar ratio was $1.8 \pm 0.6 \%$ (Table 1 ). The results of the raw flower honey samples used in the study, the protein in honey and raw honey. The difference between delta $\mathrm{C} 13$ values and the average C4 calculated from raw honey delta C13 sugar ratios are in accordance with the Turkish Food Codex Honey Communiqué found (Turkish Food Codex, 2020). In addition, our results are in harmony with the results reported by Çiftçi and Parlat (2018) on flower honeys in Konya province.

\section{Conclusion}

The physical and chemical parameters of honey, which has started to take its place in the market in recent years, defined as raw honey and not exposed to heat treatment and advanced mass production processes, were evaluated with this study. This study showed that the physical and chemical properties of Erzurum highland flower raw honey are higher than the other honeys produced in the region. This study supplies helpful data for the characterization of highland flower raw honey of Erzurum province. In this region, researchs should be carried out with a larger number of samples in a wider area.

\section{Acknowledgement}

This study was presented as an oral presentation at the Hodja Akhmet Yassawi 5th International Conference on Scientific Research which took place on Nov 5-6, 2021, in Nakhchivan State University, Azerbaijan.

\section{References}

Albu, A., Radu-Rusu, C. G., Pop, I. M., Frunza, G., \& Nacu, G. (2021). Quality assessment of raw honey issued from eastern Romania. Agriculture, 11(3), 247. https://doi.org 10.3390/agriculture11030247

Al-Sherif, A. A., Mazeed, A. M., Ewis, M. A., Nafea, E. A., Hagag, E. S. E., \& Kamel, A. A. (2017). Activity of salivary glands in secreting honey-elaborating enzymes in two subspecies of honeybee (Apis mellifera L). Physiological Entomology, 42(4), 397-403. https://doi.org/10.1111/phen.12213

Amor, D. M., (1978). Composition, properties and uses of honey- a literature survey. The British Food Manufacturing Industries Research Association, Leatherhead, UK., Scientific and Technical Surveys No. 108, 84.

AOAC, (2005). Official Methods of Analysis, 998.12: C-4 plant sugars in honey. Internal standard stable carbon isotope ratio method.

Batu, A., Küçük, E., \& Çimen, M. (2013). Doğu Anadolu ve Doğu Karadeniz Bölgeleri çiçek ballarının fizikokimyasal ve biyokimyasal değerlerinin belirlenmesi. Gıda Teknolojileri Elektronik Dergisi, 8(1), 52-62.

Bogdanov, S. (2009). Harmonized methods of the International Honey Commission. http://www.ihc-platform.net/ihcmethods2009.pdf.

Bogdanov, S., \& Martin, P. (2002). Honey authenticity: A review. Mitteilungen aus dem Gebiete der Lebensmitteluntersuchung und Hygiene, 93, 232-254.

Bogdanov, S., Jurendic, T., Sieber, R., \& Gallmann, P. (2008). Honey for nutrition and health: A review. Journal of the American College of Nutrition, 27, 677-689. https://doi.org/10.1080/07315724.2008.10719745

Bogdanov, S., Martin, P., \& Lullmann, C. (2002). Harmonised methods of the international honey commission. Swiss Bee Research Centre, FAM, Liebefeld, 5, 1-62. 
Burucu, V. (2021). Ürün Raporu Arıcılık 2021. Tarımsal Ekonomi ve Politika Geliştirme Enstitüsü Müdürlüğü (TEPGE), 30, 1-37.

Çiftci, E. (2014). Konya yöresel yayla balı ile püren balının kalite kriterleri yönünden karşılaştırılması. (Tez No. 410893) (Yüksek Lisans Tezi; Selçuk Üniversitesi Sağlık Bilimleri Enstitüsü, Konya).

Çiftçi, M., \& Parlat, S. S. (2018). Konya Bölgesindeki marketlerde satılan farklı ticari çiçek ballarının bazı kimyasal özelliklerinin Türk Gıda Kodeksi-Bal Tebliğine uygunluğunun Araştırılması. Selcuk Journal of Agriculture and Food Sciences, 32(1), 38-42.

https://doi.org/10.15316/SJAFS.2018.61

Doner, L. W. (2003). Honey. Encyclopedia of Food Sciences and Nutrition, 2, 3125-3130. London: Academic Press. 10.1016/B0$12-227055-X / 00600-3$

DIN Norm, (2002). DIN Norm 10754 Untersuchung von Honig; Bestimmung des Prolingehaltes von Honig.

Erdoğan, Y., Dodoloğlu, A., \& Zengin, H. (2004). Farklı çevre koşullarının bal kalitesi üzerine etkileri/Effect of different environmental conditions on honey quality. Atatürk Üniversitesi Ziraat Fakültesi Dergisi, 36(2), 157-162.

Erez, M., Karabacak, O., Kayci, L., Fidan, M., \& Kaya, Y. (2015). Characterization of multifloral honeys of pervari region with different properties. Türkiye Tarımsal Araştırmalar Dergisi, 2(1), 40-46. https://doi.org/10.19159/tutad.20031

Gökmen, V. (2007). Analysis of HMF By HPLC. Cost Action 927 Training School. Building Skills on the Analysis of Thermal Process Contaminants in Foods, Ankara.

Herbert, E. W. (1992). Honey bee nutrition. In Graham, J.M. (Ed). The hive and the honey bee, (pp.197-233). Datant \& Sons, Hamilton.

Kolayli, S., Yildiz, O., Sahin, H., \& Aliyazicioglu, R. (2013). Biochemistry and physicochemical properties of honey. In L.Boukraa (Ed.), Honey in Traditional and Modern Medicine (pp 21-35.). CRC Press.

Korkmaz, S. D., \& Küplülü, Ö. (2017). Effects of storage temperature on HMF and diastase activity of strained honeys. Ankara Üniversitesi Veteriner Fakültesi Dergisi,64(4), 281-287. https://doi.org/10.1501/Vetfak_0000002811
Lazaridou, A., Biliaderis, C. G., Bacandritsos, N., \& Sabatini, A. G. (2004). Composition, thermal and rheological behaviour of selected Greek honeys. Journal of Food Engineering, 64, 9-21. doi:10.1016/j.jfoodeng.2003.09.007

Machado De-Melo, A. A., Almeida-Muradian, L. B. D., Sancho, M. T., \& Pascual-Maté, A. (2018). Composition and properties of Apis mellifera honey: A review. Journal of Apicultural Research, 57(1), 5-37. https://doi.org/10.1080/00218839.2017.1338444

Özgüven, M., Demircan, E., \& Özçelik, B. (2020). Çeşitli yörelerimizde üretilen çiçek ballarının fizikokimyasal özelliklerinin belirlenmesi ve Türk Gıda Kodeksi'ne uygunluğunun değerlendirilmesi. Avrupa Bilim ve Teknoloji Dergisi, (20), 321326. https://doi.org/10.31590/ejosat.758399

Ruiz-Matute, A. I., Brokl, M., Soria, A. C., Sanz, M. L., \& MartinezCastro, I. (2010). Gas chromatographic-mass spectrometric characterisation of tri- and tetrasaccharides in honey. Food Chemistry, 120, 637-642. https://doi.org/10.1016/j.foodchem.2009.10.050

Sabatini, A.G. (2007). II miele: Origine, composizione e proprieta`. In A.G. Sabatini, L. Botolotti, \& G.L. Marcazzan (Eds.), Conscere il miele (pp. 3-37). Bologna-Milano: Avenue Media.

Şahin, H., Kolaylı, S., \& Beykaya, M. (2020). Bazı ham ve ticari ballarda ayırt edici parametre olarak invertaz ve glukoz-oksidaz aktivitesinin karşılaştırılması. Uludağ Arıcılık Dergisi, 20(1), 1323. https://doi.org/10.31467/uluaricilik.656842

Sorkun, K., Doğan, N., Gümüş, Y., Ergün, K., Bulakeri, N., \& Işık, N. (2002). Türkiye'de üretilen doğal ve yapay balların ayırt edilmesinde fiziksel, kimyasal ve mikroskobik analizleri. Mellifera, 2-4: 13-21.

Thrasyvoulou, A., Tananaki, C., Goras, G., Karazafiris, E., Dimou, M., Liolios, V., Kanelis, D., \& Gounari, S. (2018). Legislation of honey criteria and standards. Journal of Apicultural Research, 57(1), 88-96. https://doi.org/10.1080/00218839.2017.1411181

Turkish Food Codex, (2020). Turkish food codex Honey Communication (Communication No: 2020/7).

TSE, (2002). Bal Standardı. TS 3036. Türk Standartları Enstitüsü, Ankara. 